\title{
The power of fears in the travel decision - covid-19 against lack of money
}

\author{
Tamara Gajić, Marko D. Petrović, Ivana Blešić, Milan M. Radovanović and \\ Julia A. Syromiatnikova
}

(Information about the authors can be found at the end of this article.)

Received 8 March 2021 Revised 8 April 2021

21 April 2021

21 May 2021

Accepted 28 June 2021

(C) Tamara Gajić, Marko D. Petrović, Ivana Blešić, Milan M. Radovanović and Julia A. Syromiatnikova. Published in Journal of Tourism Futures.

Published by Emerald Publishing Limited. This article is published under the Creative Commons Attribution (CC BY 4.0) licence. Anyone may reproduce, distribute, translate and create derivative works of this article (for both commercial and noncommercial purposes), subject to full attribution to the original publication and authors. The full terms of this licence may be seen at http://creativecommons.org/ licences/by/4.0/legalcode

The research was supported by Ministry of Education, Science and Technological Development, Serbia (Grant No. III 47007); and from RUDN University in Program 5-100 in Russian Federation.

\begin{abstract}
Purpose-During the pandemic, two types of fear were identified that occur significantly in all groups or profiles of people. The aim of this paper is to determine which of the two types of fears exist in certain psychological groups, and which of the fears strongly influence the decision to travel.

Design/methodology/approach - The VALS 2 method and standardized questionnaire were used for the segmentation of the tourist market or for the determination of the psychographic profiles of the consumers, and three additional questions were joined to it as they were vital for the research of the type of fear and its impact on the decision for traveling. When the reliability of the questionnaire and the validity of the sample were determined, the data were further processed using a computer program package IMB AMOS SPSS 21.00, and then, based on the theoretical suppositions and hypotheses, the SEM structural model was created.

Findings - The paper indicates the existence of established types of fears in humans, when it comes to pandemics and similar crisis situations. People are most afraid of infection during travel, and lack of funds and job loss during the critical period of the pandemic. The research conducted confirms that all groups of people, who are determined by the psychological technique VALS 2, react with a certain dose of fear and make decisions under the pressure of fears.

Research limitations/implications - The research had limitations in terms of contact with people and conducting live surveys. The measures during the pandemic, which were carried out by the state, included social distance and limited movement of people.

Practical implications - The work can contribute to the community, along with similar research. The results of the research will be available, and it will be possible to see the behavior of people during crisis situations, and the impact of fears on making decisions, both travel decisions and decisions related to other areas of life.

Originality/value - The paper provides research results on a large sample of respondents, and can serve as a basis for further research in the field of tourism, psychology and similar fields. It is crucial to consider the type of fears, and the strength of the impact of these fears on the decision to travel, during crisis situations.

Keywords Pandemic, COVID-19, VALS 2, Tourism, Serbia
\end{abstract}

Paper type Research paper

\section{Introduction}

Since the beginning of the COVID-19 pandemic, at the end of December 2019 in China, about 67.7 million people have been infected and about 1.54 million have died worldwide as a result of the pandemic (https://www.bbc.com, Johns Hopkins University, the National Institutes of Health, Last updated: January 11, 2021). COVID-19 pandemics caused by the SARS-CoV-2 virus have transformed the entire globe in less than a year, leaving long-lasting consequences on the world economic flows, travel industry and each individual. The first case was recorded in China's city of Wuhan in December 2019, and on 15 June 2020, more than 3.6 million people were marked as active cases with infection in over 200 countries (Worldometer, 2020). According to Godinic et al. (2020), health risk, increasing unemployment, fear of lack of enough money for living and fear of traveling were identified as the most pressing outcomes on the global scale. The authors of this 
paper aimed to investigate the impact of two types of fear that occur in tourists of different psychological groups, when making their decision to travel.

There is not a large number of research papers on the topic of the impact of crisis situations on the behavior of tourists, and their decision-making on travel. In particular, there is a small amount of research related to examining the strength of fear of crisis situations, depending on the segmentation of the tourist profile. The new Corona virus now infects more people than the SARS virus, which spread to more than 20 countries in 2003 (Au et al., 2005; Ivanov et al., 2020; Zhang et al., 2020). Every country in the world has taken strong measures to protect the population and spread the pandemic. Borders, schools, companies were closed, production and trade has been stopped. This move affected all branches of the economy, including tourism (Ivanov et al., 2020; Gajić et al., 2020; Yanga et al., 2020). The Corona virus pandemic has made it difficult for people to move, and travel restrictions have been introduced to prevent the spread of the new virus in order to preserve the health of citizens (Zhai et al., 2019; Collin et al., 2020). What is obvious is that travel during the COVID-19 pandemic was more difficult and less frequent. Due to various restrictions, such as the need for passengers to be tested before traveling, but also due to the fear of infection during the trip, most tourists canceled their trips. Williams and Kayaoglu (2020), highlight the negative impact of the pandemic on the tourism industry and related sectors, on tourism products and service delivery. They also point out that in the tourism industry in the EU, before the pandemic, employment increased from $19.7 \%$ to $58.7 \%$, but that all kinds of restrictive measures will endanger the tourism economy. Zheng et al. (2021), in their research, point out that a pandemic can have great consequences on the behavior of tourists, through the fear that remains after the pandemic. They also point out that "passenger fear" can provoke different coping strategies, which increases people's psychological resilience and the adoption of cautious travel behavior. The recovery of the entire economy after a pandemic can be very slow, as evidenced by previous studies related to the impact of major pandemics on society and the system. Kuo et al. (2008), investigated the impact of the SARS pandemic on tourism, as well as the post-pandemic recovery. According to them it is necessary to create a relationship between tourism and crisis management to manage communicable diseases, and reduce the negative long-term consequences of this activity and the psyche of the people. Chew and Jahari (2014), in a paper entitled Destination image as a mediator between perceived risks and revisit intention: A case of post-disaster Japan, discover that the perception of risk by tourists can affect their tourist behavior after a pandemic. Post-crisis behavior has a major impact on tourist motivation for travel (Pizam and Mansfeld, 2006; Rittichainuwat, 2007; Lee et al., 2012; Yaakobi, 2015; Bali et al., 2016). Fennell (2017) points out the impossibility of overcoming the trauma after a pandemic, because that fear becomes stronger and more unpredictable, due to the primitive emotional acceptance of the threat of infection. However, the question arises, whether the fear of lack of money or the fear of infection, is stronger among tourists, during crisis situations. Nicola et al. (2020) explore the economic implications of COVID-19, and the creation of fear among consumers in spending decisions. Crisis situations, such as the pandemic period, affect the creation of strong fears among consumers, as well as the way of life and decision-making after a pandemic (Brug et al., 2004; Reisinger and Mavondo, 2005; Lepp et al., 2011; Liu et al., 2013; Cui et al., 2016; Rindrasih et al., 2019). Fears are very difficult to overcome, especially the fear of lack of money or job loss (Santana, 2003; Cahyanto et al., 2016; Gajić et al., 2018; Fotiadis et al., 2021).

However, in order to supplement similar research on the influence of fear on travel decisions, the authors expanded the research topic by pointing out the perception of the situation by different psychological groups of tourists. There are very few studies that indicate the impact of the two strongest fears that occur in people: the fear of infection and the fear of lack of money in crisis situations. The task of the research was, with the help of identified segments of tourist consumers, to determine their position on which of the two types of fear has the strongest power when making travel decisions. The VALS 2 method was used for the segmentation of tourism consumers, where the respondents were divided into eight consumer groups according to their specific questions regarding demography, attitudes, finances, product consumption and the data on the activities. According to the VALS 2 psychographic technique, tourism consumers are segmented into the 
following groups: Innovators (successful, leaders), Thinkers (educated, relaxed, complacent), Achievers (family, careerists), Experiencers (freedom as a lifestyle), Believers (traditionalists), Strivers (not independent, proving themselves to others), Makers (family, creative) and Survivors (not too ambitious and satisfied). The ESM method (Electronic Mail Survey) was used for gathering data, as well as Google docs survey service, which has already been widely used in this type of research, and it proved to be very convenient in the times where social distancing is a must. Using the data analysis performed by the program software SPSS AMOS 21.00, and the SEM analysis he total number of respondents was 2,600, and 120 respondents with complete responses (960 analyzed surveys) were taken from each group of consumers for the analysis in order to achieve the equality in the participation of all the groups. The authors came to a conclusion that both of the types of fear in almost the same amount in all the profiled groups affect making the decision for tourist traveling. Notable is the fact that the fear of lack of financial assets in the times of pandemic, also has great implications on the people's awareness. The significance of this paper is reflected in the observation of the specific impacts that a fear has on the tourism consumers' behavior, especially regarding a pandemic of a huge scale. The paper has a much wider scientific and social significance. Considering the obtained results, it is possible to apply the research in other fields and spheres of life in order to define the strategies in advance to prevent the collapse of certain economic branches, as well as the social sphere of human lives. Based on this research, and similar in the world, tourism companies could better understand consumer behavior caused by the strength and type of fear, and on the basis that they do not go too far into long-term business predictions. On the other hand, it is possible to influence tourists to overcome fear and continue to plan trips.

\section{Literature review}

\subsection{Influence of COVID-19 on tourist decisions for travel}

The impact of the pandemic on all the spheres of life is enormous. COVID-19 has caused numerous problems of social nature. In people, it also inflicted an inner conflict. On one hand, we feel a need to see our friends, to go to work and to go back to our usual pace of life, while on the other side, there is a fear of an infection. During the coronavirus pandemic and staying at home in quarantine conditions, besides the fear regarding one's own health, and the health of their beloved ones, there appeared a fear regarding the future as well (Akhoondnejad, 2015; Lee, 2020; Gossling et al., 2020). That feeling of uncertainty, when we do not know what things will be like, how long the pandemic will last, whether there will be other waves, as well as the inability to make any plans, caused an additional feeling of anxiety in people. The lack of control and the uncertainty of the infection are the greatest problems for people (Wahlberg and Sjöberg, 2000; Campiranon and Scott, 2014). To keep mental health and composure during the coronavirus pandemic and everything that follows as a consequence of the spread of the infection is almost equally important as to comply with the guidelines and advice of the World Health Organization and the local authorities (Baldwin and di Mario, 2020). The disturbance of everyday routines and new emotions produce a fear and anxiety, and thus mental health can be endangered. Corona will change life many segments - emotional, social, in close relations and in getting to know one's own self - which means it will develop the resilience and resistance to stress. Social networks and media greatly affect human fears (Brewer et al., 2007; Olstead, 2011; Yeung and Yee, 2019).

Mertens et al. (2020), in their work Fear of the coronavirus (COVID-19), Predictors in an online study conducted in March 2020, point to the types of fears that the pandemic raises: fear of infection, fear of media influence on the human psyche, and for the family, but also the fear of economic consequences. They talk about severe forms of anxiety and vulnerability that the pandemic causes. Fear of tourist travel, the very step of taking a trip, is a natural fear in people, but this fear is especially heightened during crisis situations (Fennell, 2017). Many have investigated the intensity of fear on travel after major pandemics, wars, terrorist attacks (Wahlberg and Sjöberg, 2000; Ajzen, 2002; Santana, 2003; Cooper, 2005; Liao et al., 2010; Huang et al., 2020). In their research, they come to the conclusion that such situations cause concern, anxiety, panic and the fear of risk in 
potential tourists. Exploring the fears of potential tourists in crisis situations, allows overcoming problems both in business and in people (Gu and Wall, 2006; Pffor and Hosie, 2007; Dunwoody and Griffin, 2015; Liu et al., 2016). The recovery of the tourism sector, as well as the motivation of tourists to travel without fear, can be very slow (Novelli et al., 2018). In their research, which lasted 21 months, they came to the conclusion that the recovery and readiness of tourists after the pandemic is very slow, and that it is a great challenge to work on empowering potential tourists. Rindrasih et al. (2019), in its research in Indonesia, argue that the consequences of a disaster over a long period of time are enormous, and that the continuation of regular tourism activities requires a structural approach in terms of policy responses. Lee et al. (2012), in their research paper entitled The impact of non-pharmaceutical interventions for 2009 H1N1 influenza on travel intentions: A model of goal-directed behavior, found that desire, perception of behavior control, frequency of past behavior and non-pharmaceutical interventions predicted the intention of tourists, but the perception of $2009 \mathrm{H} 1 \mathrm{~N} 1$ had no effect on desire and intention. It is necessary to investigate in the long run, the impact of crisis situations on the fear of potential tourists, if the resilience of the destination to the given situations (Prayag, 2018). To what extent the factors such as historical, political, and economic ones, affect the perception of risk and people's reaction, as well as their fears, was the subject of the research with the title SARS and New York's Chinatown: the politics of risk and blame during an epidemic of fear (Eichelberger, 2007). Also, the existence of fears and the speed of spreading the fear of infection, as well as the influence on the decision to travel, were investigated by Cahyanto et al. (2016). They conducted a survey on a total sample of 1,613 American respondents, found that perceived sensitivity and self-efficacy significantly affect Americans' avoidance of domestic travel.

Pearson et al. (2004), investigated the impact of a fear pandemic in humans, even in tourism decisions, and all the results were presented in the paper under the title Fear and stigma: the epidemic within the SARS outbreak. The results showed that the Asian-American communities were especially affected, even though fear, stigmatization and discrimination were not so widely spread in the public. Many researchers pointed to the fact that some people develop a fear related to traveling after a certain pandemic and after the declaration of its end, as well as to the extent to which the pandemic affects emotional breakdown and long-lasting consequences and fears (Champan and Skinner, 2008; Cohen, 2020). The threat of an infection may distort our psychological reactions regarding the everyday interactions, and lead to the unexpected behavior. The constant media bombing may result in the increased anxiety, with the direct impact on our mental health. But, the constant feeling of threat may have other, more perfidious effects on our psychology (Rogens, 1975). Due to certain deeply rooted reactions to an illness, the fears of infection make us become more conforming and act more like members of a tribe, and be less tolerant toward eccentricity. Our moral judgements become harsher and our social attitudes more conservative when it comes to questions such as immigration, sexual freedom and equality (De Zwart et al., 2007). Daily reminders of a disease may even change our political opinions. News on the increased xenophobia and racism may even be the first signs of the fear for traveling, but if the predictions of scientific research prove to be true, they may reflect on much deeper social and psychological changes as well. Media and social networks greatly affect the spread of fear among people and their making decisions for traveling in the future (Chew and Jahari, 2014). Some messages on health risks promote the change in the behavior (Bollen, 1989).

Yeung and Yee (2019), pointed ot the theories of motivation which they use to examine the reaction of tourists, their attitudes, ways of thinking and the protective behavior, that is the creation of a distance toward risky destinations. Maser and Weiermair (1998), pointed out that the fear is a key emotion which makes people avoid danger. Elsrud (2001), also state that fear creates a certain perception in people and they try to behave protectively when faced with the source of fear. De Zwart et al. (2007), in his research, stated that after SARS, tourists make decisions for traveling more cautiously and more anxiously. Also, he proved that the state after the pandemic greatly affected numerous spheres of life, while the decision for traveling was also affected by precaution measures, lockdown and restrictions which were in force during the pandemic. Alan et al. (2006), in their research paper Crisis management and recovery: how restaurants in Hong Kong responded 
ot SARS' pointed to all the problems that SARS caused, as well as the noticed crises, and facing them, along with the continuation of doing business by overcoming the crisis in the management. With the international travels, the possibility of a quick spreading of the infection rises (Park and Reisinger, 2010). All the warnings for travelers are of great importance due to the enormous transmission of the pandemic (Maxouris, 2020; Li et al., 2020). Considering all the research listed in the previous paragraphs, it is clear that crisis situations leave long-term consequences on people. They affect them, creating strong fears. Observing the period and consequences of the pandemic, from the beginning until today, it is clear that people will make travel decisions with a certain dose of fear. Some of them will definitely give up traveling, while others will travel anyway but quite certainly with some dose of fear of infection.

\subsection{The impact of fear of lack of money in crisis situations}

When observing the tourism sector, its unexpected end was recorded with the outbreak of COVID19 (Colin et al., 2020). Over 3 million people in the tourism sector lost their jobs (Stezhko et al., 2020; Farzanegan et al., 2020). A pandemic of an infectious disease is the suffering from an infectious disease which crosses state borders and spreads to a large part of the world or to the whole world, thus endangering people in all affected areas (Eidelman and Crandall, 2009; Lee et al., 2012). Fotiadis et al. (2021), point out that COVID-19, remains the world's deadliest epidemic that comes along with the systemic global health crisis, financial crisis and economic downturn, known as the COVID-19 recession. All destinations are forced to suspend their business after locking measures and travel bans, as well as canceled reservations and limited logistics (Polas et al., 2019; Welfens, 2020). According to UNWTO estimates, international arrivals fell by $22 \%$ in the first quarter of 2020 , and are expected to decline between $60 \%$ and $80 \%$ throughout the year, leading to a loss of between $\$ 910$ billion to $\$ 1.2$ trillion (Fotiadis et al., 2021). COVID-19, will have long-term negative consequences on the economy, and thus the loss of jobs in all sectors of the economy, which increases the fear of people regarding lack of money for life (Welfens, 2020). The occurrence of great pandemics and disasters has an enormous impact on international tourism (Sjöberg et al., 2004; Thompson and Dahling, 2019). Floyd and Pennington-Gray (2004), in their research, stated that the situation such as global financial crisis does not affect the arrival of tourists. Poudel and Subedi (2020) emphasize the negative impact of COVID-19 on people's mental health, travel decisions and economic effects, which can be manifested through people's fear of losing their jobs and lack of money. Therefore, this type of fear brings with it other fears when it comes to the life and daily activities. Blustein and Guarino (2020), examined the existential loss, anxiety and terror caused by the massive unemployment events caused by the pandemic. They point out that the loss of work is then connected to the notion of existential terror, which captures the emotional imperative to survive as well the need to manage the psychological consequences of threats that undermine existence. When people feel the fear of losing their job, and the lack of money in crisis situations, it turns into emotional terror, which further causes a change in behavior in all spheres of life. Job loss is a great force, especially in the lives of poor and marginalized individuals, whose influence is dramatically amplified in the background of the global pandemic, when the invisible threat to survival is already preparing people to experience heightened feelings, which creates existential terror. People are starting to behave differently, make decisions more modestly, give up traveling because they are in some kind of uncertainty about what will happen after the pandemic, and how to survive. Then travel becomes completely meaningless, and the fear of lack of money overcomes all kinds of fears. More than half of workers around the world are worried about losing their jobs, according to a survey measuring labor market insecurity wreaked by the Corona virus crisis. The poll of 12,430 people for the World Economic Forum showed $54 \%$ of them are either very concerned or somewhat concerned that their employment will cease in the next year. Respondents were from 27 countries spread around the world, including almost all of the group of 20 economies (https://www.thehindubusinessline.com). Existing research indicates that the fear of lack of money becomes a common fear in people, only intensified in certain crisis situations. Fear of financial losses, and the possibility of a normal existence is human everyday life. That kind of fear seems to become innate for generations, whether there are crisis situations or not. Its strength may 
be more noticeable in some periods of crisis, but it is always present in people and determines the way of life.

Based on the research on how the fear of a pandemic or infection affects the attitude of tourists to decision-making, and based on the results of research that the lack of money in crisis situations affects travel decisions, the authors set the following hypotheses:

H1. There are statistically significant differences in the assessment of fears, and the influence of fears in making travel decisions, among different groups of tourists.

H1a. There are no statistically significant differences in the assessment of fears, and the influence of fears in making travel decisions, among different groups of tourists.

H2. There is a statistically significant difference in the strength of the fear of infection and the fear of lack of money, on the prediction of potential travel by different profiles of tourists.

H2a. There is no statistically significant difference in the strength of fear of infection and fear of lack of money, on the prediction of potential travel by different profiles of tourists.

It was necessary to determine which of the two mentioned fears has a greater predictive power in decision-making by tourists about potential travel in a pandemic crisis situation.

\section{Methodology}

\subsection{Operationalization}

The first phase of the research included the determination of the research goal, gathering and analysis of secondary data (online research and the data obtained in previous research). Omnibus research was performed using: the online panel and EMS (Electronic Mail Survey). VALS 2 defines the consumers' segments based on those personal characteristics, values, attitudes, beliefs, interests and participants' activities which have a negative impact on the behavior in the market. The standardized online VALS 2 questionnaire was available on the official website of SBI (Strategic Business Insight). This e-survey uses 39 questions, 35 of which are psychological and 4 are demographic. Research, with a five-point Likert scale from 1 to 5 (I completely agree to strongly disagree). The research included the analysis of the participants' value system which is reflected through their attitudes and lifestyle. In accordance with the aims of the paper, three more questions were added based on which the existence of fear in the respondents, and its impact on the decision for traveling would be determined. Those three questions will be analyzed in this research paper. VALS 2 questionnaire was translated into the Serbian language in order to avoid misinterpretation or unequal understanding of the text in English among the respondents and interviewers. VALS 2 method was used in order to determine the psychographic profiles of the consumers, the pattern of their behavior and making decisions in tourism trends (Reisinger and Mavondo, 2005). Using the results of thousands of interviews focused on the fundamental values and the motivation of the consumers in 35 countries, Roper Starch Worldwide created six basic categories which represent a global consumer of legal age: Achievers ( $23 \%$ of the world population), Dedicated (22\%), Altruists (18\%), Intimate (15\%), Looking for fun (12\%), Creative (10 $\%)$. Inactive consumers, Active consumers, Social consumers, Traditionalists, Meticulate consumers, Rational consumers, Unstable consumers (Solomon, 1996) - VALS uses psychology in order to divide people according to their personal characteristics. In that way, it not only identifies the differences in motivation, but also the psychological and material limitations in the consumers' behavior. The VALS method was developed in the USA at Stanford Research Institute -SRI in 1978 by A. Mitchell (Eildeman and Crandall, 2009). Such a kind of segmentation is based on attitudes, interests, opinions, personal concept and lifestyle of the consumers on the market (Elsrud, 2001). The research included both qualitative and quantitative methods, which were developed based on voluminous literature. Taking into consideration that psychographic analysis is relatively complex psychological research, because using a larger sample of consumers, the results of the research presented in this paper, should be contribute to a more comprehensive 
and detailed analysis of the tourist consumers in Republic of Serbia. The application of VALS 2 method enabled a precise determination of activities and interests of the consumers and provided information on the consumers' cultural values and lifestyle. In combination with the questions related to demography and tourist travels, an insight has been provided into the representation of certain types of consumers on the tourism market and their preferences toward certain tourist destinations.

\subsection{Data collection}

The survey was distributed amongst a total of 2,600 participants in the Republic of Serbia, through an online survey, from October to December 2020. From each of the eight defined groups of tourists, the authors took 120 survey questionnaires with complete answers. This achieved equal participation of respondents from all groups. The reason for this is that there was not an equal number of complete answers from each group. In order to achieve the validity of the results, the authors decided to take a sample of 120 questionnaires from each group, which made a total of 960 analyzed questionnaires at the level of the state of the Republic of Serbia. The initial part of the research was to divide the respondents into groups, based on their characteristics, more precisely to segment tourists. However, the segmentation results will not be displayed due to the size of the survey. Only the results concerning the specific author's research will be given. There are different ways to create surveys online, and the authors chose Google Docs because the service is increasingly used, so it was the expected choice.

\subsection{Data analysis}

The initial statistical analysis, which included the descriptive statistics of the sample, was done using the IMB AMOS SPSS softver, version 21.00. Descriptive statistics were used to determine the socio-demographic profile of the respondents, and to obtain an average score for each type of fear, and decision to travel, from each identified group of tourists. The reliability of the questionnaire was checked by Cronbach's Alpha (must be above 0.07), and in this case, the value is $\alpha=0.867$, which indicates the high reliability of the questionnaire.

The fitness of the model was assessed based on the fit indices for which it was previously determined that were valid fit indices of the model (Benter and Chou, 1987; Hu and Bentler, 1999). The comparative fit index - CFI compares the existing model with the zero model and it is most often used. The values of $\mathrm{CFI} \geq 0.90$ prove the good fitness of the model. The root mean square error of approximation - RMSEA is the fit index which represents a part of the variance which is not included in the model (Benter and Chou, 1987). It represents the root mean value of the differences between the assessed and the real values. (The values of RMSEA <0.06). Also, the fit parametres, Normed fit index - NFI and Tucker-Lewis Index - TLI, were presented. To check the extent to which the model agrees with the data, the mentioned suitability indices must be calculated. Multiple suitability indicators have been taken, in order to gain insight into the quality of the model, and that any conclusion can be drawn with certainty and hypotheses confirmed.

At the same time, as another advantage of SEM, two latent variables were set which reduced the measurement error. Also, the finally obtained model, with complex interactions between the examined variables, can be graphically presented, which enables an easier insight into the examined phenomenon. The structural component of the SEM regards the paths which represent the tested theoretical interactions. The correlations between the given variables are represented by one-direction arrows, which represent the regression coefficients in the structural equations. Thus, the advantage of SEM in comparison with other multi-variance methods is the ability to simultaneously analyze multiple variables and to explain their direct and indirect correlations at the same time (Little and Rubin, 1987; Hoyle, 1995). The structural equation modeling - SEM represents a method which has the aims similar to multiple regression, but this approach is much wider, so it takes into consideration the modeling of interactions, non-linearity, related independent variables, measurement errors and multiply latent independent variables. The advantages of the 
SEM compared to multiple regression are: it includes more flexible suppositions in order to reduce the error in measuring taking into consideration the multiple indicators for each latent variable; the attractiveness of the SEM graphic display of modeling; testing the whole model before testing individual coefficients; the possibility of testing models with multiply dependent variables; the possibility of modeling indirect variables rather than introducing additional ones; the possibility of modeling the term of an error; as well as the ability of handling complex data (time series with autocorrelative errors, abnormal data, incomplete data). The most important difference between the path analysis and SEM is that SEM takes into consideration the measured and latent variables. In fact, the path analysis is a simple continuation of a multiple regression on the factors obtained from the measured variables (Hu and Bentler, 1999). The models of structural equations include the measurement model and the structural model. The measurement model determines the correlation between the measured variables and latent variables (factors), while the structural model deals with the correlation of latent variables.

\section{Results and discussion}

The category variables: age, education, gender, earning and frequency of traveling, are presented with relative (\%) frequency, using the program software SPSS 21.00. The central tendency of the numerical identifiers is presented by the arithmetic mean $(m)$, and the dispersion uses the standard deviation (SD). The distribution of numerical identifiers frequency was examined by skewness and kurtosis indicators. The reliability of the questionnaire was determined by Cronbach's alpha coefficient. The internal reliability of the used questionnaire is 0.80 (Cronbach's alpha coefficient $\alpha=0.867$, with the standardization of $\alpha=0.863$ ).

Out of the total number of participants, $24.4 \%$ belong to the age group of $31-50$, and $40 \%$ of the participants were over 50 years old. Male population comprised $53.4 \%$, while $46.6 \%$ of them were women. As for the education structure, 38.2\% completed secondary school, $45.7 \%$ had a university degree, and $16 \%$ had MSc and PhD diplomas. The participants in the research declared that $5.8 \%$ of them travel once a week, $37.2 \%$ once a month, while $57 \%$ travel even less frequently. The total of $26.8 \%$ of the participants earn less than 300 euros a month, followed by $44.1 \%$ who earn between 300 and 500 euros, and only $29.2 \%$ earn more than 500 euros a month.

Table 1 shows the average ratings for each identified group of potential tourists. The highest average score was given to the group Achievers $m=3.88(S D=1,127)$. Then, the Believers group carries the value of the arithmetic mean $m=3.80$, while the Strivers group has a score of 3.54 $(S D=1.044)$. The group Survivors was rated 3.56 , while the lowest average rating among all groups is Innovators $m=2.18$.

Table 2 shows the average grades and the standard deviation for each item of research by groups. The Innovators Group rated Fear of lack of money $m=2.29$ with the highest score. As for the tourists who belong to the Thinkers group, they gave the highest score for the item Fear affects the decision $m=2.96$. The group Achievers rated the item Fear of infection during a trip with the

\section{Table 1 Descriptive statistics for the psychographic groups}

\begin{tabular}{lcr} 
VALS 2 groups $(\mathrm{N}=960)$ & $\mathrm{m}$ & $S D$ \\
\hline Innovators & 2.18 & 1.061 \\
Thinkers & 2.91 & 1.052 \\
Achievers & 3.88 & 1.127 \\
Experiencers & 2.16 & 0.860 \\
Believers & 3.80 & 1.104 \\
Strivers & 3.54 & 1.044 \\
Makers & 3.05 & 0.779 \\
Survivors & 3.56 & 1.021
\end{tabular}

Source(s): Author's research, ${ }^{*} m=$ arithmetic means, $S D=$ standard deviation 
highest score ( $m=3.92)$. The group of potential tourists Believers, with also the highest fear of infection on the trip ( $m=3.79$ ), as well as the group of Strivers, who gave the highest score to the fear of infection $(m=3.62)$. Respondents who made up the Makers group gave a high score to the item Fear affects the decision $(m=3.14)$, and members of the Survivors group were most afraid of infection.

Table 3 provides insight into the descriptive values for both types of fear, the strength of which is explored, as well as for the verse that fear influences decision making. It can be noticed that the fear of lack of money $(m=3.14)$ took a slightly higher score than the fear of infection $(m=3.12)$. generally observed, both types of fear have almost equal impact on potential tourists, from all psychographic research groups. Also, both types of fear equally influence the decision to travel. These data confirm the alternative hypothesis $\mathrm{H} 1 \mathrm{a}$, that there are no statistically significant differences in different groups of tourists, when it comes to assessing the type of fear and the impact on decision-making on travel.

In order to determine which of the fears can most predict the decision on future travel, an SEM analysis was performed. Structural model agreement (SEM) indicators are given in Table 4. In this case, the model has achieved the appropriate fit indices, which means that the model fits perfectly.

The model had the following values of the fit index: The $\chi^{2}$ test yields a value of 1644.503 which, evaluated with 252 degrees of freedom, has a corresponding $p$-value of 0.00 . This $p$-value is too high to reject the null of a good fit. Chi-square is an observation of a random variable that has an approximate chi distribution with 252 degrees of freedom. The graph shows items, manifest variables, as well as the latent variables Covid Fear (CF) and Decision for traveling (D.F.T). Standardized factor loads, values of direct and indirect effects, as well as errors, are shown in the graph. Table 5 gives an overview for Regression Weights (Estimate, SE, CR). The correlation between the variables (measured and latent) is shown in the measurement model. One of the main benefits of the latent variables is that they are without any random error. The error connected with latent variables is statistically assessed and removed in the SEM analysis.

Table 2 Descriptive statistics for the questions according to groups

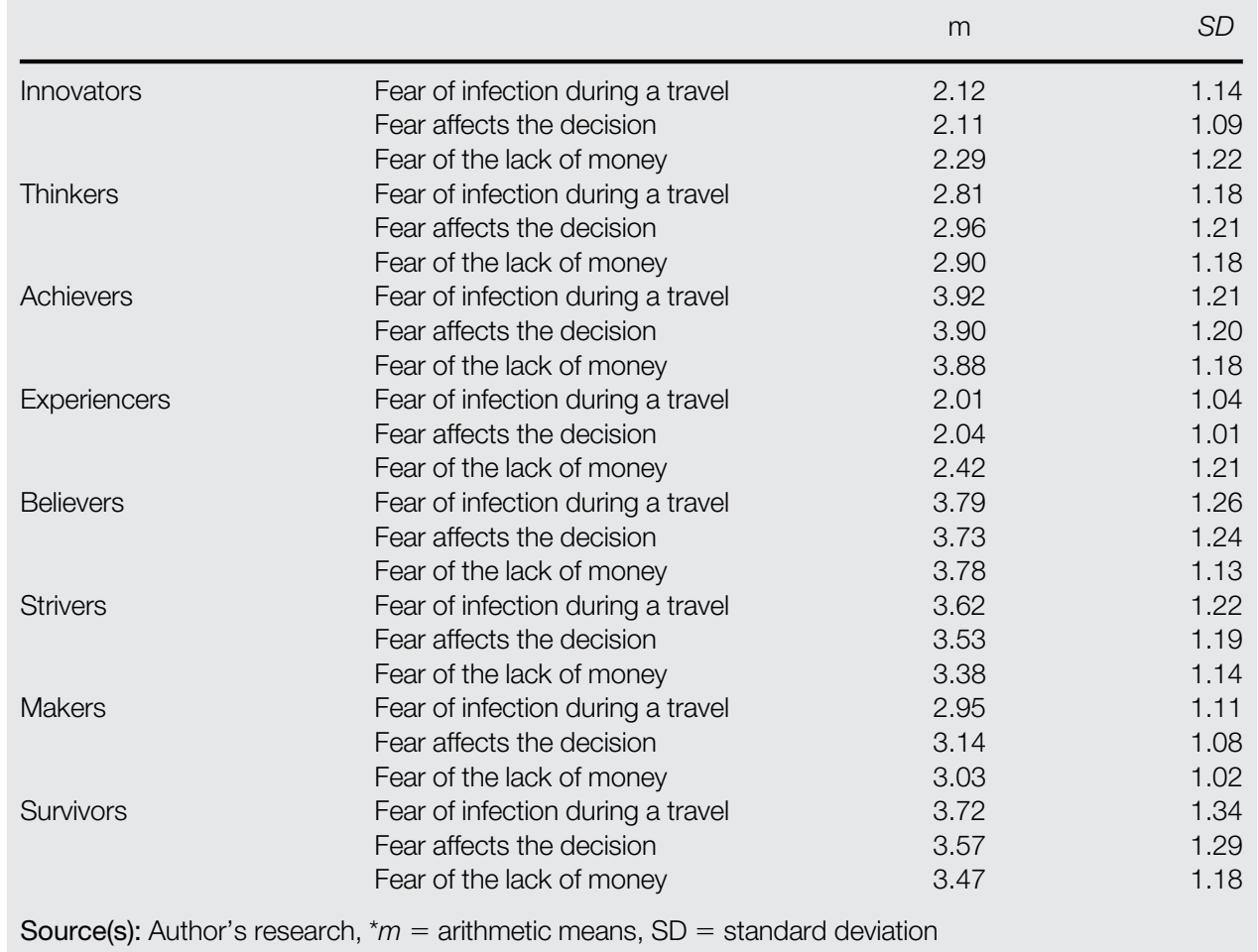

PAGE 70 |JOURNAL OF TOURISM FUTURES $\mid$ VOL. 9 NO. 12023 
Table 3 Descriptive statistical analysis for all the types of fear

Variable

m

$S D$

Fear of infection

3.12

0.45

Fear of the lack of money

3.14

0.45

Fear affects the decision

3.12

0.47

Source(s): Author's research, ${ }^{\star} m=$ arithmetic means, $\mathrm{SD}=$ standard deviation

Table 4 Fit statistics of the measurement model

\begin{tabular}{lcr} 
Fit statistic & Recommended & Obtained \\
\hline CFI & $>0.90$ & 0.996 \\
RMSEA & $<0.06$ & 0.033 \\
NFI & $>0.90$ & 0.894 \\
TLI & $>0.90$ & 0.933 \\
Source(s): Author's research & &
\end{tabular}

Table 5 presents the estimated values for the covariances between groups and D.F.T (decision for traveling). For the Innovators group, the covariance is estimated to be 0.119 . For Thinkers group covariance is estimated to be 0.145 . Achievers group has the estimated covariance of 0.103 , and for the Experiencers it is 0.112. The estimated covariance for the Believers group is 0.133 , while it is 0.101 for the Strivers group. The researched group of Makers has the estimated covariance of 0.171 , while it is estimated to be 0.145 for the Survivors group.

Observing the covariance of each first question (11, T1, A1, E1, B1, S1, M1, SU1) for each group of respondents, SPSS AMOS set the value of 1.000 (Table 6). The covariance of $\mathrm{I} 2$ is estimated at 0.961 , with an estimate of the standard covariance error $\mathrm{SE}=0.175$. Estimate 0.961 is an observation of an approximately normally distributed random variable centered around the covariance of a population with a standard deviation of 0.175 . These figures serve to construct a 95\% confidence interval on the covariance population by calculating Estimate and SE. The Critical Ratio (CR) was obtained by dividing the covariance estimate by its standard error. At a statistical significance of $p<0.05$, any CR exceeding 1.96 is considered significant. If this value is achieved, it is considered that the covariance between the variables differs significantly from 0 , at the level of significance $p<0.05$. It is noticed that this value is above $1.96(5.480)$, therefore it can be concluded that the fear of the lack of money significantly affects the decision for traveling. The covariance $\mathrm{I} 3$ has an estimation of about 0.887 , with standard covariance error $\mathrm{SE}=0.141$, and also very significant influence on D.F.T $(p=0.00, C R=6.291)$. A large $p$ in addition to $C R$ gives about two tailed $p$-values to test the hypothesis. In this case, the covariance between the variables differs from 0 . Calculation $p$ implies that parameter estimates are normally distributed, and are

Table 5 Regression weights of groups and decision for traveling (D.F.T)

Estimate

Innovators $\rightarrow$ D.F.T

0.119

Thinkers $\rightarrow$ D.F.T

0.145

Achievers $\rightarrow$ D.F.T

0.103

Experiencers $\rightarrow$ D.F.T

0.112

Believers $\rightarrow$ D.F.T

0.133

Strivers $\rightarrow$ D.F.T

0.101

Makers $\rightarrow$ D.F.T

0.171

Survivors $\rightarrow$ D.F.T

0.145

Source(s): Author's research, *D.F.T decision for traveling 


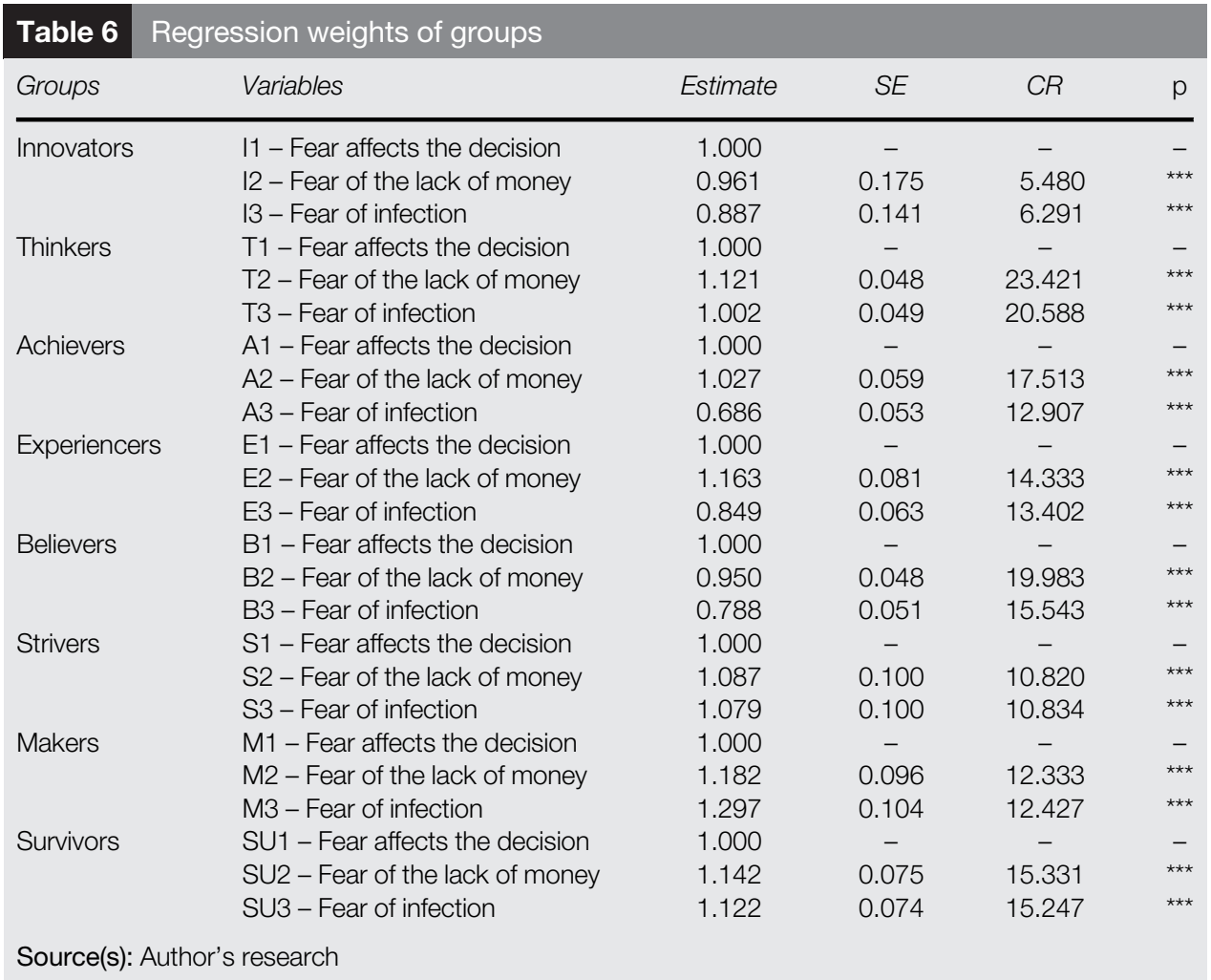

accurate only in large samples. For the Thinkers group T2, the covariance value is estimated to be 1.121, with a standard error estimate of $S E=0.048$. The CR value is 23.421 , which is greater than 1.96 , and is considered significant, which is confirmed by the value of $p$, which is 0.00 . For group T3 the covariance value is estimated to be 1.002 ( $S E=0.049, C R=20.588, p=0.01$ ). These data indicate that Thinkers group has an impact on D.F.T. Estimate of the A2 covariance is very high 1.027, with a standard error estimate of SE 0.059. Critical Ratio (CR) is 17.513, with a value of $p=0.00$. A3 covariances values are: estimate 0.686, $\mathrm{SE}=0.053, \mathrm{CR}=12.907, p=0.01$. Covariance $\mathrm{E} 2$ has estimate of about 1.163, with $\mathrm{SE}=0.081$, and $\mathrm{CR}=14.333$. The data indicate that the fear of the lack of money has a significant influence on the D.F.T $(p=0.00)$. Values for covariance $\mathrm{E} 3$ are: estimate $=0.849, \mathrm{SE}=0.063, \mathrm{CR}=13.402$. The covariance Believers $\mathrm{B} 2$ is estimated to be 0.950 , and B3 0.788 . It can be noticed from the same table that the covariance Strivers 2 is estimated to be 1.087, while the covariance S3 is 1.079 . The estimates of the covariances Makers 2 and Makers 3 are very high ( $\mathrm{M} 2=1.182$ and M1.297, respectively). Also, the values of the covariance SU2 is estimated to be 1.142 (SE $=0.75, C R=15.331$ ), and SU3 is estimated to be 1.122 ( $\mathrm{SE}=0.74, \mathrm{CR}=15.247, p=0.00$ ). The results show that the covariance Fear of COVID-19 affects the decision to travel in all the groups.

The Standardized Regression Weights can be interpreted as the correlation between the observed variable and the corresponding common factor. All the eight variables have moderate to strong standardized loadings on the factor. They are all reliable indicators for D.F.T. Observing the Innovators group, it has the lowest loadings on D.F.T (0.54). Standardized loadings on Thinkers are 0.083 , but Achievers group also has very low standardized loadings on the factor $(0.085)$. The Experiencers item has low estimate (0.075), but Believers have the highest loadings on the factor with the estimate of 0.089 . Strivers group has the estimate of 0.066 . Makers and Survivors have similar estimates (above 0.070). Table 7. shows the Standardized regression weights for each question from each group. 
Table 7 Standardized regression weights

\begin{tabular}{|c|c|c|c|c|c|c|}
\hline Groups & Variables & $\begin{array}{l}\text { Standardized } \\
\text { regression weights }\end{array}$ & Estimate & $S E$ & $C R$ & $p$ \\
\hline \multirow[t]{3}{*}{ INNOVATORS } & 11 - Fear affects the decision & 0.555 & 3.719 & 0.043 & 85.934 & 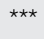 \\
\hline & 12 - Fear of the lack of money & 0.755 & 4.073 & 0.031 & 133.350 & $\star \star \star$ \\
\hline & I3 - Fear of infection & 0.490 & 3.650 & 0.043 & 83.975 & *** \\
\hline \multirow[t]{3}{*}{ THINKERS } & T1 - Fear affects the decision & 0.857 & 3.984 & 0.036 & 111.834 & $\star \star \star ~$ \\
\hline & T2 - Fear of the lack of money & 0.947 & 3.987 & 0.036 & 110.376 & *** \\
\hline & T3 - Fear of infection & 0.836 & 4.032 & 0.037 & 110.237 & *** \\
\hline \multirow[t]{3}{*}{ ACHIEVERS } & A1 - Fear affects the decision & 0.879 & 2.053 & 0.050 & 41.145 & 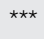 \\
\hline & A2 - Fear of the lack of money & 0.924 & 2.146 & 0.049 & 44.012 & $\star \star \star ~$ \\
\hline & A3 - Fear of infection & 0.616 & 2.454 & 0.049 & 50.288 & $\star \star \star ~$ \\
\hline \multirow[t]{3}{*}{ EXPERIENCES } & E1 - Fear affects the decision & 0.776 & 2.721 & 0.046 & 59.182 & *** \\
\hline & E2 - Fear of the lack of money & 0.896 & 2.857 & 0.046 & 61.661 & *** \\
\hline & E3 - Fear of infection & 0.704 & 2.727 & 0.043 & 63.322 & $\star \star \star ~$ \\
\hline \multirow[t]{3}{*}{ BELIEVERS } & B1 - Fear affects the decision & 0.916 & 3.881 & 0.039 & 100.434 & 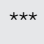 \\
\hline & B2 - Fear of the lack of money & 0.887 & 3.881 & 0.038 & 102.388 & 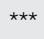 \\
\hline & B3 - Fear of infection & 0.701 & 3.753 & 0.040 & 94.406 & *** \\
\hline \multirow[t]{3}{*}{ STRIVERS } & S1 - Fear affects the decision & 0.685 & 2.525 & 0.051 & 49.293 & 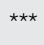 \\
\hline & S2 - Fear of the lack of money & 0.768 & 3.244 & 0.050 & 65.327 & *** \\
\hline & S3 - Fear of infection & 0.754 & 2.655 & 0.050 & 52.895 & *** \\
\hline \multirow[t]{3}{*}{ MAKERS } & M1 - Fear affects the decision & 0.720 & 4.117 & 0.030 & 136.536 & *** \\
\hline & M2 - Fear of the lack of money & 0.728 & 3.865 & 0.035 & 109.648 & 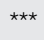 \\
\hline & M3 - Fear of infection & 0.857 & 4.008 & 0.033 & 122.005 & *** \\
\hline \multirow[t]{13}{*}{ SURVIVORS } & SU1 - Fear affects the decision & 0.758 & 4.095 & 0.035 & 115.392 & 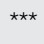 \\
\hline & SU2 - Fear of the lack of money & 0.854 & 4.074 & 0.036 & 113.110 & *** \\
\hline & SU3 - Fear of infection & 0.833 & 4.050 & 0.036 & 111.804 & *** \\
\hline & & \multicolumn{5}{|c|}{ Estimates } \\
\hline & D.F.T $\rightarrow$ C.F & \multicolumn{5}{|c|}{0.099} \\
\hline & D.F.T $\rightarrow$ Innovators & \multicolumn{5}{|c|}{0.054} \\
\hline & D.F.T $\rightarrow$ Thinkers & \multicolumn{5}{|c|}{0.083} \\
\hline & D.F.T $\rightarrow$ Achievers & \multicolumn{5}{|c|}{0.085} \\
\hline & D.F.T $\rightarrow$ Experiencers & \multicolumn{5}{|c|}{0.075} \\
\hline & D.F.T $\rightarrow$ Believers & \multicolumn{5}{|c|}{0.089} \\
\hline & D.F.T $\rightarrow$ Strivers & \multicolumn{5}{|c|}{0.066} \\
\hline & D.F.T $\rightarrow$ Makers & \multicolumn{5}{|c|}{0.070} \\
\hline & D.F.T $\rightarrow$ Survivors & \multicolumn{5}{|c|}{0.073} \\
\hline
\end{tabular}

The squared multiple correlations (Table 8) provide information on how much variance the common factors account for in the observed variables. Despite receiving a path from both latent variables. In addition, the $R^{2}$ corresponding to all of the 24 observed variables indicate that the respective factor explains a respectable portion of the variance (between $24 \%$ and $89.6 \%$ ). \%). In the order of the increasing magnitude for the group of Makers the remaining $R^{2}$ statistics are: M3 0.735 ; $\mathrm{M} 2-0.530$ and $\mathrm{M} 1-0.518$. For the group of Strivers: $\mathrm{S} 3$ is 0.569 , S2 is 0.590 and $\mathrm{S} 1$ is 0.469 . The remaining $R^{2}$ statistics for Believers are: B3 -0.492 , B2 -0.787 , B1 -0.839 . The squared multiple correlations for Experiencers are: $E 3-495$, E2 - 802 and E1 - 0.602. The results for the Achievers are the following: $\mathrm{A} 3-0.380 ; \mathrm{A} 2-854 ; \mathrm{A} 1-0.772$. The highest $R^{2}$ is the one for the Thinkers group has T21 -0.734 , followed by, T2 -0.896 and T3 -0.698 . The squared multiple correlations for Survivors are SU3 - 0.694; SU2 -0.729 and SU1 -575 . Finally, the squared multiple correlations for Innovators group are: 13 - 0.240; 12 - 0.570; 11 - 0.308 (see Figure 1).

Innovators, also known as Actualisers, are described as successful, sophisticated, with a high level of self-respect, wide perspective, and the tendency of taking the leadership. They are interested in the growth and they tend to develop, realize and express themselves in various ways sometimes they are led by principles, wishes for positive emotions and changes. These people are among the established and rising leaders in the business and public administration, but they are still striving for complex tasks for themselves. They have a wide range of interests, care for social 
Table 8 Squared multiple correlations for the groups and latent variables

\begin{tabular}{|c|c|c|}
\hline \multirow[t]{3}{*}{ Makers } & M3 - fear of infection & 0.735 \\
\hline & M2 - Fear of the lack of money & 0.530 \\
\hline & M1 - Fear affects the decision & 0.518 \\
\hline \multirow[t]{3}{*}{ Strivers } & S3 - Fear of infection & 0.569 \\
\hline & S2 - Fear of the lack of money & 0.590 \\
\hline & S1 - Fear affects the decision & 0.469 \\
\hline \multirow[t]{3}{*}{ Believers } & B3 - Fear of infection & 0.492 \\
\hline & B2 - Fear of the lack of money & 0.787 \\
\hline & B1 - Fear affects the decision & 0.839 \\
\hline \multirow[t]{3}{*}{ Experiencers } & E3 - Fear of infection & 0.495 \\
\hline & E2 - Fear of the lack of money & 0.802 \\
\hline & E1 - Fear affects the decision & 0.602 \\
\hline \multirow[t]{3}{*}{ Achievers } & A3 - Fear of infection & 0.380 \\
\hline & A2 - Fear of the lack of money & 0.854 \\
\hline & A1 - Fear affects the decision & 0.772 \\
\hline \multirow[t]{3}{*}{ Thinkers } & T3 - Fear of infection & 0.698 \\
\hline & T2 - Fear of the lack of money & 0.896 \\
\hline & T1 - Fear affects the decision & 0.734 \\
\hline \multirow[t]{3}{*}{ Survivors } & SU3 - Fear of infection & 0.694 \\
\hline & SU2 - Fear of the lack of money & 0.729 \\
\hline & SU1 - Fear affects the decision & 0.575 \\
\hline \multirow[t]{3}{*}{ Innovators } & I3 - Fear of infection & 0.240 \\
\hline & 12 - Fear of lack of money & 0.570 \\
\hline & 11 - Fear affects the decision & 0.308 \\
\hline C.F & & 0.046 \\
\hline D.F.T & & 0.064 \\
\hline
\end{tabular}

issues, and are open for changes. The research showed that the average assessment for the fears that affect the decision for traveling is above 2 (Fear of infection during a travel is 2.12 ( $S D=1.22$ ); The fear that affects the decision is 2.11 ( $S D=1.09)$; Fear of the lack of money is $2.29(\mathrm{SD}=1.22)$ ). The regression weight for Innovators is estimated to be 0.119 . The remaining minimum $R^{2}$ statistics for this group is the Fear of infection with 0.240 , but the largest is the Fear of lack of money with $R^{2}=0.570$.

Thinkers are mature, self-satisfied, relaxed and motivated by ideals. They cherish order, education and responsibility. They are mostly highly-educated and active in the search for information when making decisions. They are well-informed about the global and national events and they do not miss a chance to widen their knowledge. They respect social authorities and institutions to a certain extent. They are calm, self-assured, practical - they buy things that are functional, valuable and long-lasting. The values for their profile would be: Fear of infection during a travel: 2.81 (SD =1.18); Fear affects the decision: 2.96 ( $S D=1.21$ ); Fear of the lack of money: 2.90 (SD =1.18). Through the regression weights it can be concluded that all the variables affect the Fear of COVID-19 and the decision for traveling. For the Thinkers group, the Regression Weights covariance is estimated to be 0.145 . The minimum $R^{2}$ statistics is for the item Fear of infection (0.698), but the maximum for the Fear of the lack of money is estimated as $R^{2}=0.896$.

Achievers are success-driven and with a life goal. They focus their lifestyle toward the family and career. They avoid situations that require greater involvement and changes. They are deeply dedicated to their job and family. The work gives them a feeling of duty, material reward, or prestige. Their social life is built around their family, Church, career. Achievers are politically conservative, and they respect authorities. Their image is very important to them - that is why they love the established and well-known, prestigious products or services that show their success to others. The average score for all the answers was good: Fear of infection during a travel: 3.92 (SD = 1.21); Fear affects the decision: 3.90 (SD = 1.20) Fear of the lack of money: $3.88(S D=1.18)$. The Achievers group has the estimated regression weight of 0.103 . Minimum squared multiple 
(3) $\longrightarrow$ INNOVATORS1

(2) $\longrightarrow$ INNOVATORS2 7.76 INNOVATORS

(1) $\longrightarrow$ INNOVATORS3

(ब6) $\longrightarrow$ THINKERS

(es) $\longrightarrow$ THINKERS2

(44) $\longrightarrow$ THINKERS3

(99) $\longrightarrow$ ACHIEVERS

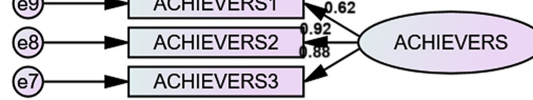

(i) $\longrightarrow$ ACHIEVERS3

1112 $\rightarrow$ EXPERIENCERS1
(11) $\rightarrow$ EXPERIENCERS2 2.90
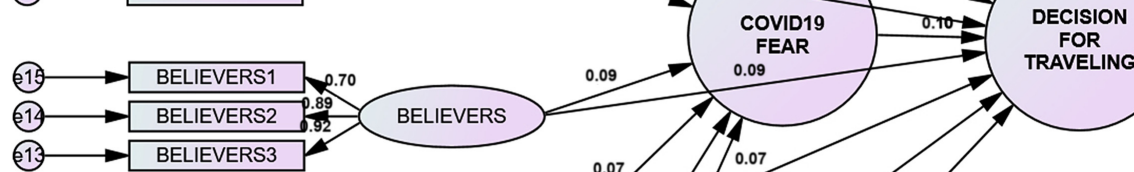

(13) BELIEVERS3

(12) $\rightarrow$ STRIVERS

(11) $\longrightarrow$ STRIVERS2

(11) $\longrightarrow$ STRIVERS3

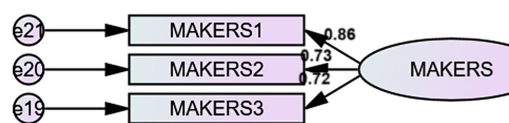

11

MAKERS3
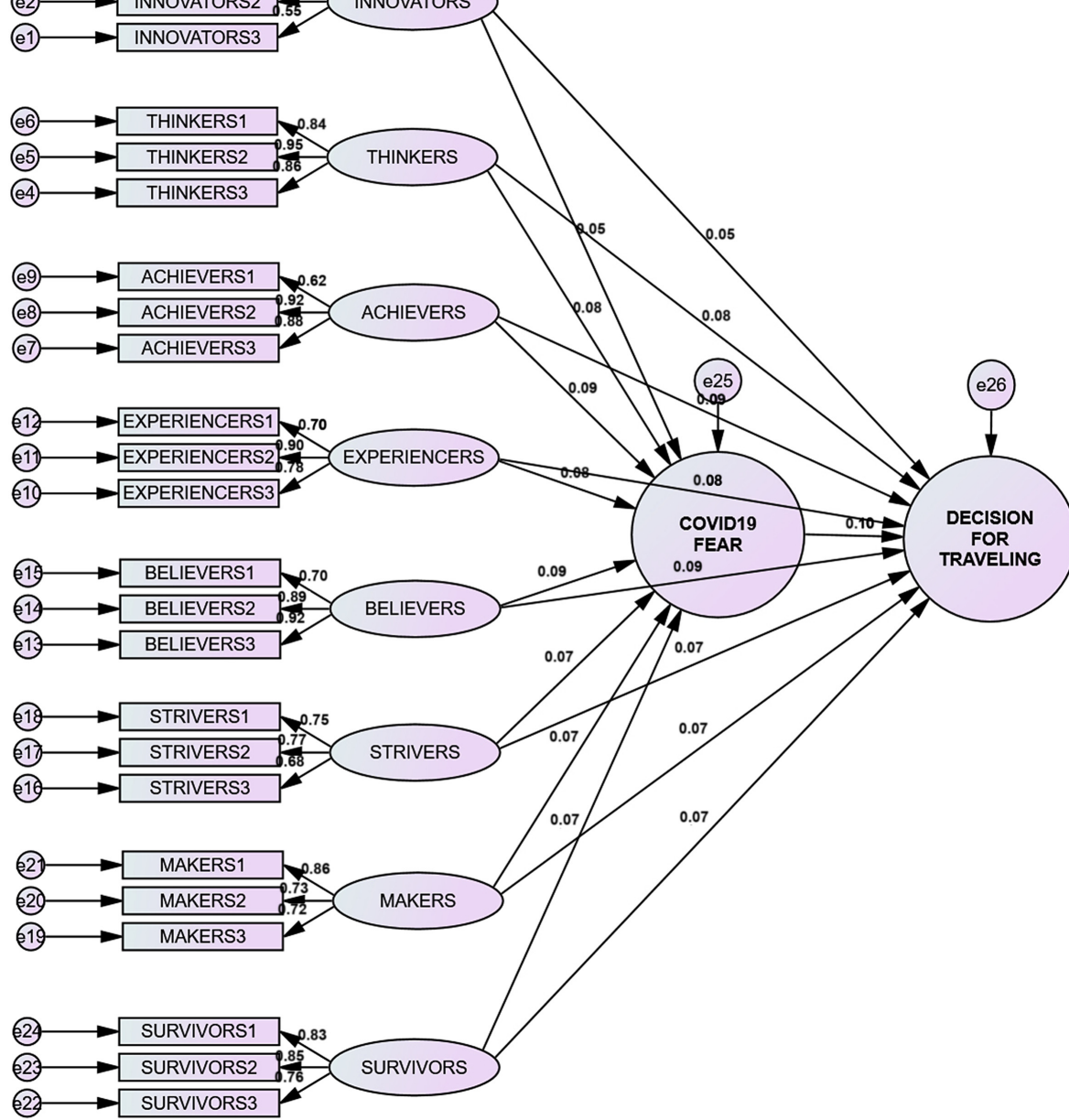

0
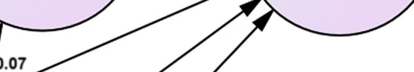

correlation is found in the item Fear of infection $R^{2}=0.380$, but the largest is the item Fear of the lack of money $R^{2}=0.854$.

Experiencers love unconventional lifestyle and freedom. They are motivated by self-assertion. They are mainly of younger age with pronounced enthusiasm. They are active and impulsive in search of stimuli which are new, risky, and challenging. They are young, energetic, enthusiastic, impulsive, and rebellious. They look for various and vivid impressions, and strive toward new, unusual, risky. They are still in the process of formulating their life values and behavior, with the enthusiasm to accept new opportunities, but they soon abandon them. Their attitudes are politically neutral, uninformed, and ambivalent. The average value of the arithmetic mean for the given variables is: Fear of infection during a travel: 2.01 ( $S D=1.04$ ); Fear affects the decision: 2.04 ( $\mathrm{SD}=1.01$ ); Fear of the lack of money: 2.42 ( $S D=1.21$ ). Regression weights for the Experiencers are estimated to be 0.112 . Minimum squared multiple correlation is for the item Fear of infection $\left(R^{2}=0.495\right)$, but the item with the largest value is Fear of the lack of money $\left(R^{2}=0.802\right)$.

Believers are traditionalists and they respect rules and authorities. As in the case of Thinkers, they are essentially conservative and idealists. They have a pronounced characteristic of morality and they are predictable as consumers. They are conservative, ordinary people with specific beliefs that 
are based on traditional values - family, Church, local community, nation. They have a low level of resources and an orientation toward the principles. They are the bearers of moral principles, deeply rooted and literally interpreted. These consumers follow the routine principles of everyday life, and they are mainly connected with home, family, their social and religious organizations. This is a group of conservative and predictable consumers who prefer domestic products and established brands. Their scores are the following: Fear of infection during a travel: $3.79(\mathrm{SD}=1.26)$; Fear affects the decision: 3.73 (SD = 1.24); Fear of the lack of money: $3.78(S D=1.13)$. The average regression weight for the Believers group is 0.133 . The minimum squared multiple correlation is found for the item Fear of infection $\left(R^{2}=0.492\right)$, but the largest value is for the item Fear affects the decision $\left(R^{2}=0.839\right)$.

Strivers follow trends and look for fun. They find other people's opinion about them very important and they have a need to be accepted and successful. They are not self-assured and have a low level of economic, social and psychological resources. They are concerned about the opinions and approvals of other people. Money defines success for the aspirants, but they lack it, and it seems their life is impoverished. Aspirants easily become bored and impulsive. Many of them are trying hard to imitate the style of those who possess more impressive things. However, what they wish to have is usually something they cannot afford. The scores for this group are the following: Fear of infection during a travel: 3.62 ( $S D=1.22$ ); Fear affects the decision: 3.53 ( $S D=1.19)$; Fear of the lack of money: $3.38(S D=1.14)$. The regression weight for Strivers is 0.101 . The minimum squared multiple correlation is found for the item Fear of the lack of money $\left(R^{2}=0.590\right)$, while the largest is for the item Fear of infection $\left(R^{2}=0.569\right)$.

Makers appreciate practicality and self-sufficiency. As in the case of Experiencers, they are motivated by self-assessment. They chose constructive activities that require skillful hands. They live traditionally and spend time with their family and close friends, do handicraft and creative work. They show suspicion toward new ideas and big businesses. They are practical people with constructive skills who appreciate independence. They live in a traditional context of the family, practical work, physical entertainment, and show little interest for what is hidden beyond that context. They express themselves and experience the world - build a house, raise children, mend their cars or preserve - and they have enough skills and energy to successfully complete those projects. They respect the government, but they are against the invasion of the country and private life. They are not interested in material assets, except in buying things for practical or functional purposes. Since they prefer value to luxury, they buy essential products. The scores for this group are the following: Fear of infection during a travel: $2.95(\mathrm{SD}=1.11)$; Fear affects the decision: 3.14 $(S D=1.08)$; Fear of the lack of money: $3.03(S D=1.02)$. Makers research group has an estimated regression weight of 0.171 . The minimum squared multiple correlations for the group of Makers is for the variable Fear affects the decision $\left(R^{2}=0.518\right)$, but the largest $\left(R^{2}=0.735\right)$ is for the item Fear of infection.

Survivors (formerly known as Strugglers) lead a simple life. Since they have the lowest and limited resources, they often feel helpless because they do not have a chance to fulfil their wishes, but only the needs. They are chronically poor, low-educated, with almost no skills, or strong social relationships; they are elderly and preoccupied by their health; they are resignated and passive. Their needs are limited to meeting the essential current needs, with no tendency to self-realization. Their main concern is safety and assurance, and they are careful consumers. The scores for this group are the following: Fear of infection during a travel: 3.72 ( $S D=1.34$ ); Fear affects the decision: 3.57 (SD = 1.29); Fear of the lack of money: $3.47(\mathrm{SD}=1.18$ ). The regression weight covariance for the Survivors group is estimated to be 0.145 . The minimum squared multiple correlation is found for the item Fear of infection $\left(R^{2}=0.694\right)$, while the largest is for the item Fear of the lack of money $\left(R^{2}=0.729\right)$.

So far, a lot of research has been done on how COVID-19 affects tourism and fear among tourists, how and where to travel after a pandemic. However, there are almost no papers dealing with a comparative analysis of the impact of the two strongest fears on the decision of tourists and on their motivation. The research was done by psychographic segmentation of tourist consumers, and it 
was determined which of the above-mentioned parents most influences the decision to travel. The VALS 2 technique was used in the segmentation of tourists, but no analysis of the impact of fears on predicting future travel was done, by observing all groups determined by this technique. For this reason, the importance of this research can be noticed, which, together with all the above similar research, can contribute to the understanding of the behavior of tourists during crisis situations. In this case, it was found that all groups of tourists have almost the same fear of COVID-19, and of constant fear, lack of money or job loss, especially which intensifies during a pandemic. Hypothesis $\mathrm{H} 1 \mathrm{a}$, that there is no statistically significant difference in the intensity of fear found in different consumer groups was confirmed, as well as hypothesis $\mathrm{H} 2 \mathrm{a}$, that there is no statistically significant difference in the predictor strength of fears, when it is necessary to predict future travel by these groups of tourists. The results obtained by the authors in this study are close to those obtained by Nicola et al. (2020), which indicated an increased fear of lack of money and job loss, relative to fear of infection. Many of the authors also pointed out the fear of lack of money and job loss in crisis situations, that it is stronger than other types of fears in human life. Also, the same authors pointed out that major crisis situations significantly affect the tourism sector, its slowdown, as well as the overall economic situation and people's lives (Williams and Kayaoglu, 2020; Welfens, 2020; Stzezhko et al., 2020).

\section{Conclusion}

The global crisis which has been spreading more and more due to the pandemic of the Corona virus (COVID-19), will have the most serious impact on the sector of tourism, as it was estimated by the world experts (Thompson and Dahling, 2019). The first consequences and losses have already struck tourist agencies, hotels and hospitality facilities in Republic of Serbia. Various types of restrictions in the population's flow have long been in force in a large number of countries worldwide. Some of the countries closed their borders, a lot of people worldwide are quarantined, numerous flights have been forbidden, and some airlines have decided to cancel certain flights as a prevention measure. As the companies reduced their business travels to the minimum, the citizens also decide to cancel their travels planned in advance due to a fear of the infection spread. In Republic of Serbia, the majority of population still plan their private trips by buying the travel packages from tourist agencies, so this sector has already felt the significant consequences of the Corona virus pandemic.

World Tourism Organization, United Nations specialized agency (UNWTO) has already provided some estimates of the consequences of this crisis in the tourism sector and it is working on the measures to help the industries affected by the crisis. This organization made an announcement where it stated that the sector of tourism is currently the most affected by the spread of the coronavirus infection, with the consequences both in the offer and in the demand for travels. Due to the lockdowns and border closures and the abrupt fall in the tourist travels to the world destinations due to the pandemic of the coronavirus, the world tourism has lost around 320 billion dollars of income, as it was stated in the latest report of the World Tourism Organization (UNWTO). It stated that it was three times more than that sector lost during the global recession in the period between 2007 and 2009. The fall in the international tourist arrivals of $20-30 \%$ would mean the fall in the income from tourism by $300-400$ billion dollars, which is almost one-third of the income earned last year. Thus, coronavirus could affect the turnover in the world tourism in the next several years to a greater extent than the impact of the economic crisis in 2009 when the fall of $4 \%$ of the international tourist arrivals was recorded, and more than during the SARS epidemic when the fall was only $0.4 \%$, as it was stated by the World Tourism Organization.

There is a large body of research on the current topic of how COVID-19 affects tourism and tourist behavior after a pandemic. In recent years, people are paying more and more attention to travel safety and travel risks. The perception of tourist risk is a quantitative assessment of tourist security. The perception of tourist destination risk directly affects the intention of tourists to buy (Pyszczynski et al., 1990; Li et al., 2020). People have developed a fear of COVID-19, and the question is how to influence that fear to be overcome and to return to normal life. Fear is slowly turning into serious 
anxiety, into maladaptive behaviors, which can contribute to the maintenance of the disorder, however, little research has concentrated on identifying and measuring these behaviors (Mahoney et al., 2018). It is assumed that the tourist experience, the tourist attitude and the influence of the media increase the making of tourist decisions with the mediating effect of risk perception. The findings confirm a positive significant link between the tourist experience and the influence of the media on risk perception (Polas et al., 2019). The COVID-19 pandemic had a great impact on our lives, especially the decision to go on a tourist trip during and after the pandemic. However, the fear of lack of money and job loss is also one of the strong fears in people. Especially if it is about some crisis situations in which the destination is located, or the whole world, as is the case when COVID-19 appeared. The economy has come to a complete standstill. Many people have lost their jobs, the final consequences are yet to be seen. The question is whether the end is in sight, and how long-term the consequences will be. There are not many researches on the topic that influences the decision of tourists to travel more than fears. Relying on previous literature and research, and noticing the lack of research on the issue of comparative analysis of the impact of the two strongest fears in tourists, the authors determined the strength of fears and their perceptions in tourists when making travel decisions.

The authors of this paper performed an online survey. It was an omnibus research where only a part of the research was taken, the one that related to the topic of the fear of COVID-19 which affects the decisions for traveling, i.e. the extent of the risk of the fear of COVID-19 regarding the development of the tourism activity. The total of 960 complete questionnaires were selected, and the analysis was carried out using the SPSS AMOS softver, version 21.00 version. Descriptive statistical analysis determined the average scores for all groups of tourists, which are grouped according to VLAS 2, psychology technique. Using a structural model (SEM), it was possible to determine the predictor strength of each fear in predicting potential travel, in each group of tourists. SEM analysis was used to set the latent variables in order to avoid errors. The latent variables were free from random errors which is why the errors were calculated and eliminated, leaving only the general variance. The standardized questionnaire with VALS 2 method of segmentation of the tourism market was used, and three additional key questions crucial to the research were added to the already known questionnaire. All the fit indices of the SEM model were within the limit of acceptance and relevance, so the further analysis of the regression and the squared multiple correlations were performed. The descriptive statistical analysis confirmed that all the eight groups of consumers have close values regarding the attitude toward the impact of COVID-19 on the decision for traveling. The participants in the consumer groups of Thinkers and Innovators have the average scores a bit above 2 for both of the types of fears, while other groups of participants have clearly more pronounced fears regarding the decision for traveling. The SEM analysis determined that all the questions in all the selected VALS 2 groups of tourist consumers express the fear of COVID-19 toward D.F.T., and that $p=0.00$ for all the questions, which indicates that it is statistically significant for the research. Each of the questions, more precisely, both types of fears and the decision for traveling have statistically significant values, i.e. they express a significant attitude of resistance of the selected groups toward D.F.T. With the presented research, the authors came to the following conclusions:

1. Both types of fear have an equal impact on all profiles of tourists, and almost equally determine the decision to travel.

2. Fear of lack of money in a crisis situation, as well as fear of infection during the trip, have statistical significance in predicting travel for all tourists, but as predictors of travel between these two types of fear, there is no statistically significant difference in predictive power.

It is very debatable, which of the two fears at a given time can be stronger in predicting travel, in different segments of tourists. Their values proved to be almost equal. As it has already been mentioned, similar research which has been performed by Eichelberger with the title "SARS and New York's Chinatown: the politics of risk and blame during an epidemic of fear" (2007) where she also came to the similar conclusions regarding the power of epidemic impact on the risk of tourist travels. Also, the existence of fears and the impact of SARS on traveling were also researched by 
Person et al. (2004). The research has an enormous economic and social significance, and it can be used as a base for expanding the number of current attitudes on fears caused by corona after more than a year, and for taking an earlier insight into the consequences that such types of fears may cause to certain industries, and for preventing the complete disaster.

If we take into account the fact that during a pandemic there is great panic and fear, the practical implications of this research are clear in this case. It is very important to notice the type and severity of fear in tourists, and to adopt a strategy to alleviate fear. Therefore, any future crisis situation could be prevented by certain measures, and people's fears would be significantly lower and the tourism business would suffer lower losses. Research on the type and severity of fear among tourists can contribute to the tourist offer of some appropriate solutions, in order to encourage a rapid recovery of the tourism sector and all services after the pandemic. By controlling human fear, social and practical benefits are achieved in the field of tourism business. The given results suggest that the fear of infection is not the only and strongest, and that it is their perception of a pandemic and other factors, and all this can lead to a situation that after a pandemic they cannot cope with fears and do not travel long. It is very important that this and similar research, in practice, contribute to the understanding of fear, and that all those who work in the tourism industry, adopt strategic measures to return tourism to normal as soon as possible, after the pandemic. Following the different profiles of trusts, and the type and severity of fear, the tourist offer can, with the help of various measures of employment, gain the trust of each individual, because the survey data may be relevant to the global level. Tourists are certainly, thanks to fears, taught that during the trip, respect all protection measures, and this will be in the minds of consumers and providers of the tourism industry for many years.

\section{References}

Ajzen, I. (2002), "Perceived behavioral control, self-efficacy, locus of control, and the theory of planned behavior", Journal of Applied Social Psychology, Vol. 32 No. 4, pp. 665-683.

Akhoondnejad, A. (2015), "Analysing the pre-travel, on-travel, and post-travel behaviours of Iran's first- time visitors", Journal of Travel and Tourism Marketing, Vol. 32 No. 8, pp. 1023-1033.

Alan, C.B., So, S. and Sin, L. (2006), "Crisis management and recovery: how restaurants in Hong Kong responded ot SARS”, International Journal of Hospitality Management, Vol. 25 No. 1, pp. 3-11.

Au, A.K., Ramasamy, B. and Yeung, M.C. (2005), "The effects of SARS on the Hong Kong tourism industry: an empirical evaluation”, Asia Pacific Journal of Tourism Research, Vol. 10 No. 1, pp. 85-95.

Baldwin, R. and di Mauro, B.W. (2020), Economics in the Time of COVID-19, Centre for Economic Policy Research, London.

Bali, S., Stewart, K.A. and Pate, M.A. (2016), "Long shadow of fear in an epidemic: fearonomic effects of Ebola on the private sector in Nigeria", BMJ Global Health, Vol. 1 No. 3, pp. 1-16.

Benter, P.M. and Chou, C.P. (1987), "Practical issues in structural modeling", Sociological Methods and Research, Vol. 16 No. 1, pp. 78-117.

Blustein, D.L. and Guarino, P. (2020), "Work and unemployment in the time of COVID-19: the existential experience of loss and fear", Journal of Humanistic Psyhologz, Vol. 60 No. 5, 002216782093422.

Bollen, K.A. (1989), Structural Equations with Latent Variables, John Wiley and Sons, Hatcher, New York, NY.

Brewer, N.T., Chapman, G.B., Gibbons, F.X., Gerrard, M., McCaul, K.D. and Weinstein, N.D. (2007), "Metaanalysis of the relationship between risk perception and health behavior: the example of vaccination", Health Psychology, Vol. 26 No. 2, pp. 136-145.

Brug, J., Aro, A.R., Oenema, A., De Zwart, O., Richardus, J.H. and Bishop, G.D. (2004), "SARS risk perception, knowledge, precautions, and information sources, The Netherlands", Emerging Infectious Diseases, Vol. 10 No. 8, p. 1486.

Cahyanto, I., Wiblishauser, M., Pennington-Gray, L. and Schroeder, A. (2016), "The dynamics of travel avoidance: the case of ebola in the US", Tourism Management Perspectives, Vol. 20, pp. 195-203. 
Campiranon, K. and Scott, N. (2014), "Critical success factors for crisis recovery management: a case study of Phuket hotels", Journal of Travel and Tourism Marketing, Vol. 31 No. 3, pp. 313-326.

Chapman, V.L. and Skinner, C.S. (2008), "The health belief model", in Glanz, K., Rimer, B.K. and Viswanath, K. (Eds), Health Behavior and Health Education: Theory, Research, and Practice, Jossey-Bass, pp. 45-65.

Chew, E.Y.T. and Jahari, S.A. (2014), "Destination image as a mediator between perceived risks and revisit intention: a case of post-disaster Japan", Tourism Management, Vol. 40, pp. 382-393.

Cohen, J. (2020), Individual Freedom or Public Health? A False Choice in the Covid Era, Covid-19 Ethics Resource Center, Hastings Bioethics Forum, Public Health.

Colin, C., Williams and Aysegul, K. (2020), "COVID-19 and undeclared work: impacts and policy responses in Europe", The Service Industries Journal, Vol. 40 Nos 13-14, pp. 914-931.

Cooper, M. (2005), "Japanese tourism and the SARS epidemic of 2003", Journal of Travel and Tourism Marketing, Vol. 19 Nos 2/3, pp. 117-131.

Cui, F., Liu, Y., Chang, Y., Duan, J. and Li, J. (2016), "An overview of tourism risk perception”, Natural Hazards, Vol. 82 No. 1, pp. 643-658.

De Zwart, O., Veldhuijzen, I.K., Elam, G., Aro, A.R., Abraham, T., Bishop, G.D., Richardus, J.H. and Brug, J. (2007), "Avian influenza risk perception, Europe and Asia", Emerging Infectious Diseases, Vol. 13 No. 2, p. 290.

Dunwoody, S. and Griffin, R.J. (2015), "Risk information seeking and processing model in", in Cho, H., Reimer, T. and McComas, K.A. (Eds), The Sage Handbook of Risk Communication, SAGE, Thousand Oaks, CA, pp. 102-116.

Eichelberger, L. (2007), "SARS and New York's Chinatown: the politics of risk and blame during an epidemic of fear", Social Science and Medicine, Vol. 65 No. 6, pp. 1284-95.

Eidelman, S. and Crandall, C.S. (2009), "A psychological advantage for the status quo", Social and Psychological Bases of Ideology and System Justification, Vols 85-106.

Elsrud, T. (2001), "Risk creation in traveling: backpacker adventure narration", Annals of Tourism Research, Vol. 28 No. 3, pp. 597-617.

Farzanegan, M.R., Gholipour, H.F., Feizi, M., Nunkoo, R. and Andargoli, A.E. (2020), "International tourism and outbreak of coronavirus (COVID-19): a cross-country analysis", Journal of Travel Research, Vol. 60 No. 3, pp. 687-692.

Fennell, D.A. (2017), "Towards a model of travel fear", Annals of Tourism Research, Vol. 66 No. C, pp. 140-150.

Floyd, M.F. and Pennington-Gray, L. (2004), "Profiling risk perceptions of tourists", Annals of Tourism Research, Vol. 31 No. 4, pp. 1051-1054.

Fotiadis, A., Polyzos, S., Cheng, T. and Huan, T.C. (2021), "The good, the bad and the ugly on COVID-19 tourism recovery", Annals of Tourism Research, Vol. 87, 103117.

Gajić, T., Penić, M., Vujko, A. and Petrović, M.D. (2018), "Development perspectives of rural tourism policy comparative study of rural tourism competitiveness based on perceptions of tourism workers in Slovenia and Serbia", Eastern European Countryside, Vol. 24 No. 1, pp. 143-154.

Gajić, T., Petrović, D.M., Radovanović, M., Tretiakova, T.N. and Syromiatnikova, J.A. (2020), "Possibilities of turning passive rural areas into tourist attractions through attained service quality", European Countryside Journal, Vol. 12 No. 2, pp. 179-276.

Godinic, D., Obrenovic, B. and Khudaykulov, A. (2020), "Effects of economic uncertainty on mental health in the COVID-19 pandemic context: social identity disturbance, job uncertainty and psychological well-being model", International Journal of Innovation and Economic Development, Vol. 6 No. 1, pp. 61-74.

Gössling, S., Scott, D. and Hall, C.M. (2020), "Pandemics, tourism and global change: a rapid assessment of COVID-19", Journal of Sustainable Tourism, Vol. 29 No. 1, pp. 1-20.

Gu, H. and Wall, G. (2006), "SARS in China: tourism impacts and market rejuvenation", Tourism Analysis, Vol. 11 No. 6, pp. 367-379.

Hoyle, R. (1995), Structural Equation Modeling: Concepts, Issues and Applications, Sage Publications, Thousand Oaks, CA.

Hu, L. and Bentler, P.M. (1999), "Cutoff criteria for fit indexes in covariance structure analysis: conventional criteria versus new alternatives", Structural Equation Modeling, Vol. 6 No. 1, pp. 1-55.

PAGE 80 JOURNAL OF TOURISM FUTURES $\mid$ VOL. 9 NO. 12023 
Huang, X., Dai, S. and Xu, H. (2020), "Predicting tourists' health risk preventative behaviour and travelling satisfaction in Tibet: combining the theory of planned behaviour and health belief model", Tourism Management Perspectives, Vol. 33, 100589.

Ivanov, S., Webster, C., Stoilova, E. and Slobodskoy, D. (2020), Biosecurity, Automation Technologies and Economic Resilience of Travel, Tourism and Hospitality Companies, CEO, Sezam24.com - Booking Analytics company, Prague, doi: 10.31235/osf.io/2hx6f.

Kuo, H., Chen, C.C., Tseng, W.C., Ju, L.F. and Huang, B.W. (2008), "Assessing impacts of SARS and Avian Flu on international tourism demand to Asia", Tourism Management, Vol. 29, pp. 917-928.

Lee, J. (2020), "Mental health effects of school closures during COVID-19", Child and Adolescent Health, Vol. 4 No. 6, p. 421.

Lee, C.K., Song, H.J., Bendle, L.J., Kim, M.J. and Han, H. (2012), "The impact of non-pharmaceutical interventions for 2009 H1N1 influenza on travel intentions: a model of goal-directed behavior", Tourism Management, Vol. 33 No. 1, pp. 89-99.

Lepp, A., Gibson, H. and Lane, C. (2011), "Image and perceived risk: a study of Uganda and its official tourism website", Tourism Management, Vol. 32 No. 3, pp. 675-684.

Li, J., You, Z., Wang, Q., Zhou, Z., Quu, Y., Luo, R. and Ge, X. (2020), "The epidemic of 2019-novelcoronavirus (2019-nCoV) pneumonia and insights for emerging infectious diseases in the future", Microbes and Infection, Vol. 22 No. 2, pp. 80-85.

Liao, Q., Cowling, B., Lam, W.T., Ng, M.W. and Fielding, R. (2010), "Situational awareness and health protective responses to pandemic influenza A (H1N1) in Hong Kong: a cross-sectional study", PLoS One, Vol. 5, e13350.

Little, R.J.A. and Rubin, D.A. (1987), Statistical Analysis with Missing Data, John Wiley and Sons, Loehlin, New York NY.

Liu, B., Pennington-Gray, L. and Schroeder, A. (2013), "Images of safe tourism destinations in the United States held by African Americans", PASOS. Revista de Turismo y Patrimonio Cultural, Vol. 11 No. 3, pp. 105-121.

Liu, B., Schroeder, A., Pennington-Gray, L. and Farajat, S.A.D. (2016), "Source market perceptions: how risky is Jordan to travel to?", Journal of Destination Marketing and Management, Vol. 5 No. 4, pp. 294-304.

Mahoney, A.E., Hobbs, M.J., Newby, J.M., Williams, A.D. and Andrews, G. (2018), "Maladaptive behaviours associated with generalized anxiety disorder: an item response theory analysis. Behavioural and Cognitive", Psychotherapy, Vol. 46 No. 4, pp. 479-496.

Maser, B. and Weiermair, K. (1998), "Travel decision-making: from the vintage point of perceived risk and information preferences", Journal of Travel and Tourism Marketing, Vol. 7 No. 4, pp. 107-121.

Maxouris, C. (2020), "US could be in for 'a bad fall and a bad winter' if it's unprepared for a second wave of coronavirus, Fauci warns”, CNN Interview, (accessed 30 April 2020).

Mertens, G., Gerritsen, L., Duijndama, S., Saleminkblris, E. and Engelhard, M. (2020), "Fear of the coronavirus (COVID-19): predictors in an online study conducted in March 2020", Journal of Anxiety Disorders, Vol. 74, 102258.

Nicola, M., Alsafi, Z., Sohrabi, C., Kerwan, A., Al-Jabir, A., losifidis, C., Agha, M. and Agha, R. (2020), "The socio-economic implications of the coronavirus pandemic (COVID-19): a review", International Journal of Surgery (London, England), Vol. 78, pp. 185-193.

Novelli, M., Burgess, L.B., Jones, A. and Ritchie, B.W. (2018), “No Ebola. . . still doomed'-The Ebola-induced tourism crisis", Annals of Tourism Research, Vol. 70, pp. 76-87.

Olstead, R. (2011), "Gender, space and fear: a study of women's edgework", Emotion, Space and Society, Vol. 4 No. 2, pp. 86-94.

Park, K. and Reisinger, Y. (2010), "Differences in the perceived influence of natural disasters and travel risk on international travel”, Tourism Geographies, Vol. 12 No. 1, pp. 1-24.

Person, B., Sy, F., Holton, K., Govert, B. and Liang, A. (2004), "Fear and stigma: the epidemic within the SARS outbreak", Emerging Infectious Diseases, Vol. 10 No. 2, pp. 358-363.

Pforr, C. and Hosie, P. (2007), "Crisis management in tourism: preparing to recovery", Journal of Travel and Tourism Marketing, Vol. 23 No. 4, pp. 249-264. 
Pizam, A. and Mansfeld, Z. (2006), "Toward a theorz of tourism security", Tourism, Security and Safety, pp. 1-27.

Polas, R.H., Imtiaz, M., Mahbub, A. and Khan, A.M. (2019), "Antecedent and consequences of risk perception on tourist decision making towards the sustainable medical tourism development in Bangladesh", Journal of Tourism Management Research, Vol. 6 No. 1, pp. 93-108.

Poudel, K. and Subedi, P. (2020), "Impact of COVID-19 pandemic on socioeconomic and mental health aspects in Nepal”, The International Journal of Social Psychiatry, Vol. 66 No. 8, pp. 748-755.

Prayag, G. (2018), "Symbiotic relationship or not? Understanding resilience and crisis management in tourism”, Tourism Management Perspectives, Vol. 25 No. 2018, pp. 133-135.

Pyszczynski, T., Greenberg, J., Solomon, S. and Hamilton, J. (1990), "A terror management analysis of selfawareness and anxiety: the hierarchy of terror", Anxiety Research, Vol. 2 No. 3, pp. 177-195.

Reisinger, Y. and Mavondo, F. (2005), "Travel anxiety and intentions to travel internationally: implications of travel risk per- ception”, Journal of Travel Research, Vol. 43 No. 3, pp. 212-225.

Rindrasih, E., Witte, P., Spit, T. and Zoomers, A. (2019), "Tourism and disasters: impact of disaster events on tourism development in Indonesia 1998-2016 and structural approach policy responses", Journal of Service Science and Management, Vol. 12, pp. 93-115.

Rittichainuwat, B. (2007), "Responding to disaster: Thai and Scandinavian tourists' motivation to visit Phuket, Thailand", Journal of Travel Research, Vol. 46, pp. 422-432.

Rogers, R.W. (1975), "A protection motivation theory of fear appeals and attitude changed", Journal of Psychology, Vol. 91 No. 1, pp. 93-114.

Santana, G. (2003), "Crisis management and tourism", Journal of Travel and Tourism Marketing, Vol. 15 No. 4, pp. 299-321.

Sjöberg, L., Moen, B.E. and Rundmo, T. (2004), "Explaining risk perception. An evaluation of the psychometric paradigm in risk perception research", Rotunde, Vol. 84, pp. 1-33.

Solomon, M. (1996), Consumer Behavior Buying, Having and Being, 3rd ed., Pearson Education, Prentice Hall, Upper Saddle River, New Jersey, NJ, p. 315.

Stezhko, N., Oliinyk, Y., Polishchuk, L., Tyshchuk, I., Parfinenko, A. and Markhonos, S. (2020), "International tourism in the system of modern globalisation processes", International Journal of Management (IJM), Vol. 11 No. 3, pp. 97-106.

Thompson, M.N. and Dahling, J.J. (2019), "Employment and poverty: why work matters in understanding poverty”, American Psychologist, Vol. 74 No. 6, pp. 683-694.

Wahlberg, A.A. and Sjöberg, L. (2000), "Risk perception and the media", Journal of Risk Research, Vol. 3 No. 1, pp. 31-50.

Welfens, J.J.P. (2020), "Macroeconomic and health care aspects of the coronavirus epidemic: EU, US and global perspectives", International Economy Policy, Vol. 23, pp. 1-68.

Williams, C.C. and Kayaoglu, A. (2020), "COVID-19 and undeclared work: impacts and policy responses in Europe", The Service Industries Journal, Vol. 40 No. 13, pp. 914-931.

Worldometer (2020), "Countries where COVID-19 has spread", available at: www.Worldometer.info (accessed 15 June 2020).

Yaakobi, E. (2015), "Desire to work as a death anxiety buffer mechanism", Experimental Psychology, Vol. 62 No. 2, pp. 110-122

Yanga, Y., Zhang, H. and Chen, X. (2020), "Coronavirus pandemic and tourism: dynamic stochastic general equilibrium modelling of infectious disease outbreak", Annals of Tourism Research, Vol. 83, doi: 10.1016/j. annals.2020.102913 (accessed 21 April 2020).

Yeung, R.M.W. and Yee, W.M.S. (2019), "Travel destination choice: does perception of food safety risk matter?", British Food Journal, Vol. 122 No. 6, pp. 1919-1934.

Zhai, X., Zhong, D. and Luo, Q. (2019), "Turn it around in crisis communication: an ABM approach", Annals of Tourism Research, Vol. 79, p. 10280.

Zhang, K., Hou, Z. and Li, J. (2020), "Threat of infectious disease during an outbreak: influence on tourists' emotional responses to disadvantaged price inequality", Annals of Tourism Research, Vol. 84, 102993.

PAGE 82 | JOURNAL OF TOURISM FUTURES | VOL. 9 NO. 12023 
Zheng, D., Luo, Q. and Ritchie, B. (2021), "Afraid to travel after COVID-19? Self-protection, coping, and resilience against pandemic' travel fear", Tourism Management, Vol. 83, doi: 10.1016/j.tourman.2020. 104261.

\section{Author affiliations}

Tamara Gajić is based at the Singidunum University, Faculty of Tourism and Hotel Management, Belgrade, Serbia and Senior research, South Ural State University, Institute of Sports, Tourism and Service, Chelyabinsk, Russia.

Marko D. Petrović is based at the Geografski Institut Jovan Cvijić Srpske Akademije Nauka I Umetnosti, Beograd, Serbia and Institute of Sport Tourism and Service, South Ural State University (National Research University), Chelyabinsk, Russian Federation.

Ivana Blešić is based at the Institute of Sport Tourism and Service, South Ural State University (National Research University), Chelyabinsk, Russian Federation and Department for Geography, Tourism and Hotel Management, University of Novi Sad, Subotica, Serbia.

Milan M. Radovanović is based at the Institute of Sport Tourism and Service, South Ural State University (National Research University), Chelyabinsk, Russian Federation and Geografski Institut Jovan Cvijić Srpske Akademije Nauka I Umetnosti, Beograd, Serbia.

Julia A. Syromiatnikova is based at the Institute of Sport Tourism and Service, South Ural State University (National Research University), Chelyabinsk, Russian Federation.

\section{Corresponding author}

Tamara Gajić can be contacted at: tamara.gajic.1977@gmail.com

For instructions on how to order reprints of this article, please visit our website: www.emeraldgrouppublishing.com/licensing/reprints.htm Or contact us for further details: permissions@emeraldinsight.com 